\title{
Impact of COVID-19 on mental health in a Low and Middle- Income Country
}

\author{
Impacto do COVID-19 na saúde mental em um país de baixa e \\ média renda
}

Luís Fernando Silva Castro-de-Araujo (https://orcid.org/0000-0002-0952-5052) ${ }^{1}$

Daiane Borges Machado (https://orcid.org/0000-0003-2959-4650) ${ }^{1}$

${ }^{1}$ Rede CoVida - Ciência, Informação e Solidariedade, Center of Data and Knowledge Integration for Health (CIDACS). R. Mundo 121/Parque Tecnológico do Edf. Tecnocentro/315, Trobogy. 41745-715 BA Salvador Brazil.

ldearaujo@unimelb.edu.au

\begin{abstract}
Mental disorders (MD) are commonly comorbid with cardiovascular, metabolic, and some infectious diseases. Since the current SARSCoV-2 epidemic is affecting the most multimorbid individuals, we might expect that the epidemic will be particularly problematic for people with MD. Understanding the burden of an outbreak on mental health is fundamental to effective action towards containing the spread of the disease, as psychopathology might reduce endurance during the lockdown. This can potentially reduce adhesion to ongoing treatment resulting in avoidable recurrence of a disorder. Additionally, there is the stress caused by the eminent risk of infection or economic uncertainty, especially in low-middle income settings. This is an overview on the expected influence of the COVID-19 on mental health from a research group that has not long ago been involved in the Zika epidemic. It aims to discuss the effects of the pandemic on a Low and Middle-Income country (LMIC), Brazil.
\end{abstract}

Key words COVID-19, Mental health, Brazil, Dementias, Bipolar disorder
Resumo Os Transtornos Mentais (TM) são comorbidades comuns associadas a doenças cardiovasculares, metabólicas e algumas doenças infecciosas. Como a atual epidemia de SARS-CoV-2 está afetando mais os indivíduos multimórbidos, podemos esperar que a epidemia seja particularmente problemática para pessoas com TM. Compreender o ônus de um surto na saúde mental é fundamental para uma ação de contenção eficaz da propagação da doença, pois a psicopatologia pode reduzir a resistência durante o confinamento. Que pode potencialmente reduzir a adesão ao tratamento em andamento, resultando na recorrência evitável de um distúrbio. Além disso, há o estresse causado pelo risco eminente de infecção ou incerteza econômica, especialmente em ambientes de baixa e média renda. Esta é uma "overview" sobre a potencial influência do COVID-19 na saúde mental realizada por um grupo de pesquisa que não faz muito tempo esteve envolvido na epidemia de Zika. Ela tem como objetivo discutir os efeitos da pandemia do COVID-19 em um país de baixa e média renda, Brasil.

Palavras-chave COVID-19, Saúde mental, Brasil, Demências, Transtorno bipolar 


\section{Introduction}

This is one of the few moments in which humanity has had to deal with a virus that made us question the way how society is organized, how we relate to others, and how we work. For many people it has also had a financial impact, bringing instability to their jobs and income, particularly in Low and Middle-Income countries (LMIC) where typically there are limited social protective measures.

Mental disorders (MD) are commonly comorbid with cardiovascular, metabolic, and some infectious diseases. Since the current SARS$\mathrm{CoV}-2$ epidemic is affecting the most multimorbid individuals, we might expect that the epidemic will be particularly problematic for people with MD.

Understanding the burden of an outbreak on mental health is fundamental to effective action towards containing the spread of the disease, as psychopathology might reduce endurance during the lockdown. This can potentially reduce adhesion to ongoing treatment resulting in avoidable recurrence of a disorder. Additionally, there is the stress caused by the eminent risk of infection or economic uncertainty, especially in low-middle income settings.

This is an overview on the expected influence of the COVID-19 on mental health from a research group that has not long ago been involved in the Zika epidemic. It aims to discuss the effects of the pandemic on a Low and Middle-Income country (LMIC), Brazil.

\section{COVID-19 pandemic effect on Mental Health}

Although we have faced coronaviruses epidemics before (SARS, MERS) the current new coronavirus epidemic is unprecedented due to limited treatment options. The rapid spread on the globe has generated strain on countries' ability to keep their economies afloat. Altogether these factors constitute a recipe for anxiety and stress in the overall population, but especially among vulnerable groups. Although we will only assess the real impact of COVID-19 on mental health after the pandemic, we must now adopt strategies to mitigate its effect.

Social isolation is related to numerous symptoms. It is known that epidemics can elicit anxiety and anticipation of possible infection, which sometimes manifests itself as health anxiety. It is an exaggerated preoccupation with one's own health and usually presents itself with some type of body vigilance in which the subject focuses excessively on body signs such as, palpitations, respiratory rate, and so on. Behavioural cognitive theory models it as a result of mistaken beliefs on our own health, which leads to unreasonable interpretations of body sensations. Such psychological response to stress appeared, for example, in women during the Zika epidemic ${ }^{1}$. These can persist and evolve to more intense symptoms such as anxiety and panic attacks ${ }^{2}$. Naturally, this takes a higher toll on subjects, which already have a $\mathrm{MD}^{3}$.

Misleading information from news outlets and social media can exacerbate restlessness. We are now familiar with headlines touting the new record on infections and deaths over the last 24 hours, which is presumed since it is well known that the condition spreads at an exponential rate ${ }^{4}$. This arguably increases anxiety and worsens matters for people restrained in their homes. Since this state has been lasting at least two months in Brazil, with several more months of some kind of social distance expected in the future, the extended hypervigilant state can potentially activate the hypothalamic-pituitary-adrenal axis and cause elevated levels of glucocorticoids. This, in turn, is related to both anxiety and depressive disorders 5 .

It is a community ordeal. It depends on our ability of adding structure to our day in order to reduce anxiety, or perhaps for the few that can, reach out to a psychotherapist that can help ameliorate the unrealistic beliefs. It also should involve journalists, as they should attempt to be more precise on their reports and avoid click baiting. Furthermore, policymakers have the opportunity to show science will be informing their decisions in health policies. When one of these agents are not acting cohesively during the pandemic, subjects who already have a MD are the ones most susceptible to the worsening of their illness.

\section{Subjects with mental disorders}

In the context of the LMIC, the epidemic will leave behind a track of recurrence of disorders. Unlike in developed countries, the prescription is usually bound to a visit to the psychiatrist, which has been considered a non-essential health service and has been severely hindered during the health crisis. The Brazilian ministry of health has issued a rule that allows prescriptions to be valid for six months $s^{6}$, however, subjects that have been caught in-between visits and used their prescriptions are 
Elderly subjects with cognitive impairment will require special attention. It is difficult to maintain daily care for elders in lockdown, as caregivers may be required in hospital settings as aides.Furthermore, their presence can simply prove unfeasible due to the risk of contamination while caring for more than one patient. It is highly recommended that caregivers reduce the number of subjects they care for to only one on top of maintaining all the required health measures and EPI use during their shift. Sometimes families will simply need to stand in for the patients as replacements for the caregivers. Furthermore, too long periods without contact with familiar faces can induce acute confusion and delirium ${ }^{7}$. It is recommended that elder subjects with cognitive impairment be quarantined with a family member whenever possible. Other causes of worsening could be related to limited refilling of prescription drugs, which hinders proper adherence to treatment. This is particularly problematic in Brazil, which has numerous regulations for distinct drug classes, sometimes not entirely known by pharmacists, often leaving patients short in prescribed number of pills needed until their follow-up visit.

\section{Bipolar disorder}

Subjects with bipolar disorder will face slightly distinct problems. Loneliness and boredom can trigger depressive symptoms $s^{3}$; these patients also commonly live in financial hardship from overspending in hypomanic episodes, which might hinder their ability to acquire and store medications according to prescription. Subjects with diagnosed bipolar disorder can become stranded from their families and usually benefit from social services or caseworkers that are tightly connected to their assisting doctors. The distribution of social services in Brazil is unequal across the states, richer states usually having better-structured services, which is arguably a point policymakers should focus on during the later phases of the epidemic.

\section{Strategies to mitigate the effect on mental health}

Most people's lives will be impacted in some way by COVID-19 over the months and maybe years to come. We consider that including mental health care in the national public health agenda to fight this pandemic will reduce long-lasting and expensive to treat psychological effects. Brazil is not preparing for these foreseeable consequences. The government is ignoring cases where mental illnesses might worsen due to the pandemic. Professional associations should be more active in relaying instructions of preventive measures for psychologists and psychiatrists.

Building strategies to guarantee that patients have access to medications and counselling during the pandemic is fundamental to avoid recurrence or worsening of the disorders. Prescription access can be addressed with rulings that extend the time allowed to fill prescriptions. Access to psychotherapy is possible through remote/online consultation methods. For instance, these are not fully regulated and are often frowned upon by professional associations in Brazil. We think that these deserve to become widely accepted strategies and should instead receive full support from government and professional associations

\section{Collaborations}

LFS Castro-de-Araujo and DB Machado contributed equally. All authors read and approved the final manuscript. 


\section{Acknowledgments}

The Wellcome Trust funds both authors with a research associate scholarship at CIDAS/Fiocruz.

\section{References}

1. Blakey SM, Abramowitz JS. Psychological Predictors of Health Anxiety in Response to the Zika Virus. J Clin Psychol Med Settings. 2017; 24(3-4):270-278.

2. Asmundson GJG, Abramowitz JS, Richter AA, Whedon M. Health Anxiety: Current Perspectives and Future Directions. Curr Psychiatry Rep. 2010; 12(4):306312.

3. Huremović D, editor. Psychiatry of Pandemics: A Mental Health Response to Infection Outbreak. Cham: Springer International Publishing; 2019.

4. Bao Y, Sun Y, Meng S, Shi J, Lu L. 2019-nCoV epidemic: address mental health care to empower society. Lancet 2020; 395(10224):e37-e38.

5. Lupien SJ, McEwen BS, Gunnar MR, Heim C. Effects of stress throughout the lifespan on the brain, behaviour and cognition. Nat Rev Neurosci. 2009; 10(6):434-445.

6. Brasil. Resolução - RDC No 357 , de 24 de março de 2020. Estende, temporariamente, as quantidades máximas de medicamentos sujeitos a controle especial permitidas em Notificações de Receita e Receitas de Controle Especial e permite, temporariamente, a entrega remota definida por programa público específico e a entrega em domicílio de medicamentos sujeitos a controle especial, em virtude da Emergência de Saúde Pública de Importância Internacional (ESPII) relacionada ao novo Coronavírus (SARS-CoV-2). Diário Oficial da União 2020; 24 mar.

7. Gofton TE. Delirium: a review. Can J Neurol Sci J Can Sci Neurol. 2011; 38(5):673-680.

Article submitted 22/04/2020

Approved 23/04/2020

Final version submitted 25/04/2020 